\title{
A NEW VIEW
}

BRADLEY MUIR, Waskesiu Lake, Saskatchewan. SOJ 2 YO

It was my first trip to the home farm in nearly a year and soon after pulling onto the gravel road I knew something had changed on the prairie landscape. What was different about those former grasslands now swapped for wheat fields?

Another look. I finally recognized the changes. In the past, on hundreds of trips "down the tracks" (the municipal grid parallels the CNR line), I could have seen telephone lines along the roadside. The poles and lines were taken for granted as 'natural' perches for the prairie birds which were the primary object of my attention.

Now gone were the sagging wires and weather worn spruce poles with their T-crossbars and blue, glass insulators, and as I drove along I began to miss the frequent and obvious company of birds once drawn to the road allowance and the man-made perches. Blackbirds, swallows, shrikes, bluebirds, meadowlarks, hawks, owls, and many more. They had been so numerous, so visible. The first place to look for a bird when on a trip by car was the roadside telephone lines. There birds perched for a preliminary survey before pursuing their prey, to announce their presence orally or, I imagine, to save some wing beats while enjoying the view across the plain.

I would count them in mile stretches. Raptors on the main poles, meadowlarks on the cross-bars and swallows uniformly spaced along the wire strands.

To imagine what the sweeping grasslands looked like a hundred years ago one would have to look through the telephone and power lines and shelter belts. But, having grown up with them, these roadside elements were part of the familiar scene. Now that the lines had disappeared, birds were far less obvious, as they dipped into the fields or ditch, grass or shrubs.

Our farm is near Colfax, Saskatchewan and lies in the heart of glacial lake Regina. The 55-mile drive from the city of Regina crosses some of the most featureless land in the province. It is an area congruent with the stereotyped

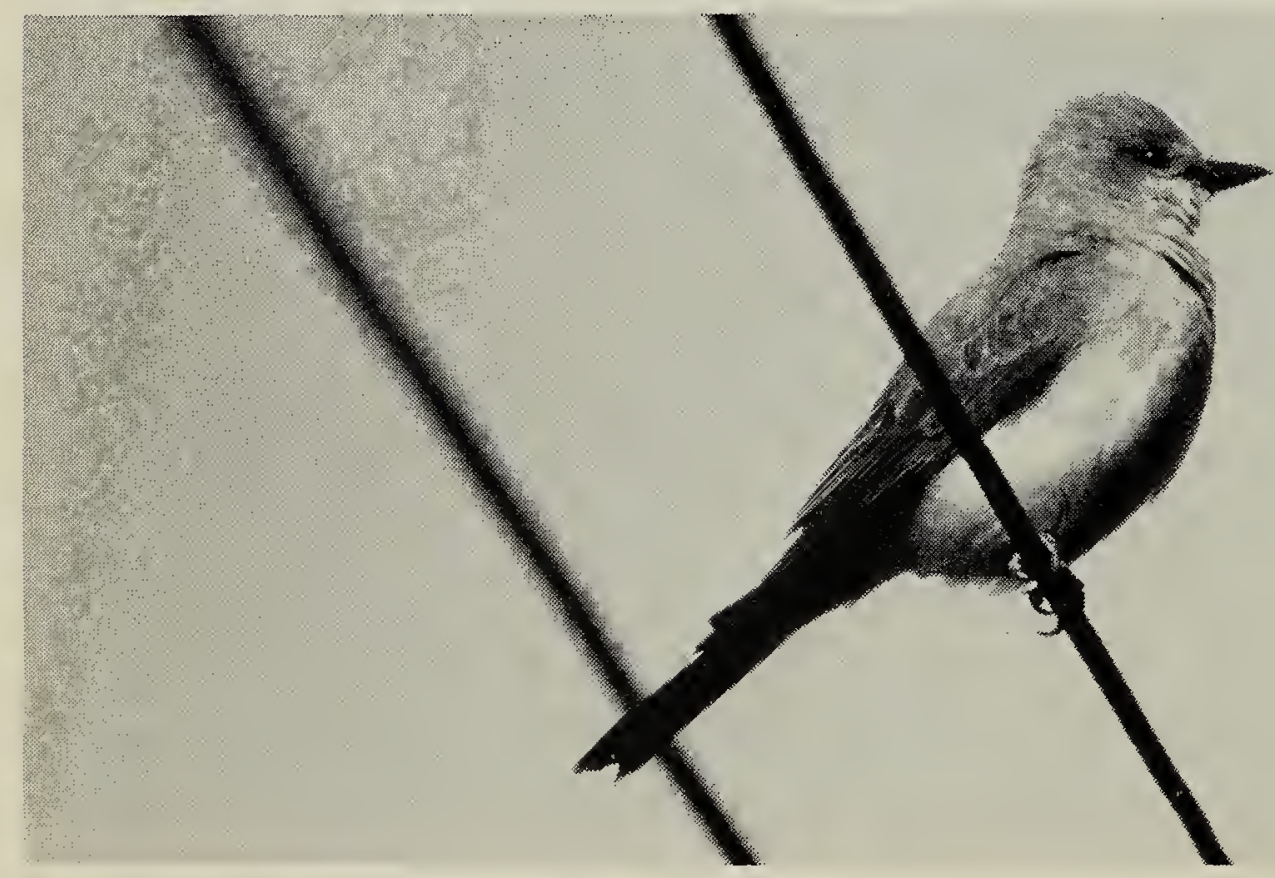

Western Kingbird.

Fred W. Lahrman 
image of the province. Miles of golden wheatland, dusty gravel roads, a dying small town every 6 miles with its attendant grain elevators and telephone party lines silhouetted in the setting sun.

In the past 5 years SaskTel has been working on its Rural Service Improvement Program (R.S.I.P.). The program has meant the removal of 57 thousand $\mathrm{km}$ of aerial open-wire lines (SaskTel Public Affairs, pers. comm.). Replacement with buried cable has been made in virtually every community in the province. It is a noticeable visual change, especially in areas like our farmstead which are gently undulating, and treeless (except for shelter belts) with willow shrubs on marsh edges. The difference is compounded by the birds being far less obvious. They are still around, spending more time in the grass and fields, on the road grade, near a marsh or soaring too high to be seen on a sunny, eye-squinting day. Locals say that there seems to be more birds occupying the poplars and carragana of the windbreaks. Birds are relocating to new perches and roosts or landing on the ground rather than telephone lines after a short interlude in the 10,000 years since the last ice-sheet melted and their ancestors recolonized the land.

Some birds may have increased their range, in part due to the tree-like perches of telephone poles. Common flickers for example extended their range from treed coulees to the grasslands. Two sources of mortality may have been reduced by the switch to underground lines. Fewer birds in flight may collide with the wire strands and fewer road-kills may occur as the "perch-magnet" has been removed.

Telephone lines went up over 50 years ago and now they have come down. The view is different across much, of the Saskatchewan plain. Chalk up another alteration to this landscape, one that this time restores a fraction of the pre-pioneer character to the prairie.
MERGANSER NEST IN CHIMNEY

TONY CAPUSTEN, 1139 River Street W., Prince Albert, Saskatchewan. S6V $3 \mathrm{~A} 2$

On 11 May 1982 a Common Merganser had 8 eggs in a nest in a chimney. This chimney was built on a bracket. There was a pipe opening about 6 . feet from the top.

On 18 May there were 11 eggs. On 23 June three young were seen in a nearby meadow. Two eggs failed to hatch; one was addled. The duck flew around, calling. The young had to cross a busy road about 100 yards down the slope and then another 100 yards to the edge of Emma Lake.

Identifcation of the adult was based on observation from a couple of feet away while the duck was incubating serrated beak shape, rufous crest, white throat patch, rufous neck, white breast. ${ }^{2}$ Observation was also made when the duck left to feed. It would leave about 10 a.m., usually to feed for about 2 hours.

'GODFREY, W. E. 1966. The birds of Canada. Nat. Mus. Can., Bull. No. 203, Biol. Ser. No. 73. Queen's Printer, Ottawa.

${ }^{2}$ PETERSON, R. T. 1941. A field guide to western birds. Houghton Mifflin Co., Boston, Mass.

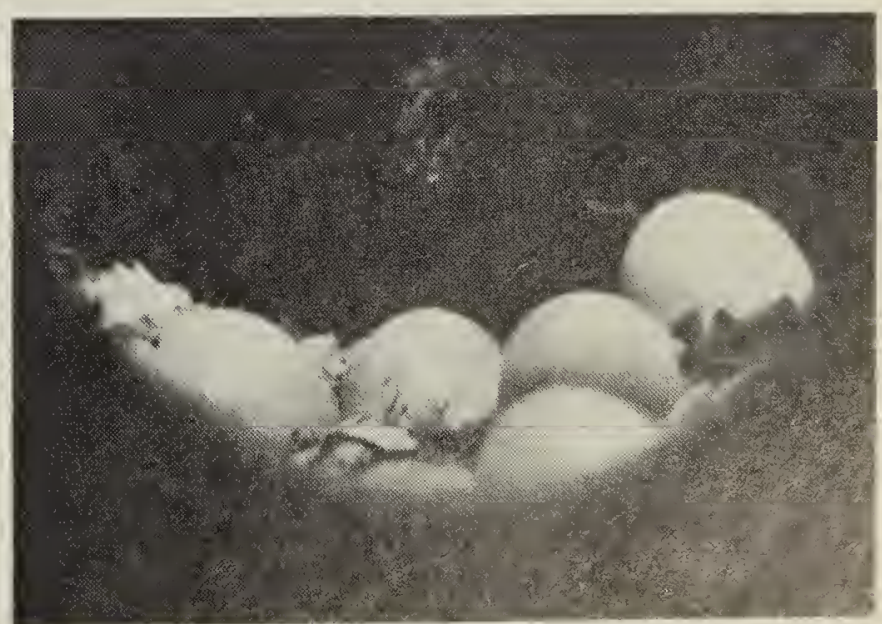

Merganser nest in chimney.

Tony Capusten 